\title{
EDUKASI PERAWATAN BALITA PADA MASA PANDEMI COVID-19 DI KELURAHAN GONDRONG, TANGERANG
}

\section{CHILDREN'S CARE EDUCATION IN THE COVID-19 PANDEMIC TIME IN GONDRONG KELURAHAN, TANGERANG}

\author{
Cintia Maulina ${ }^{1}$, Clariza Vioito ${ }^{1}$, Laras Arsyi Insani ${ }^{1}$, Ria Nuranisa ${ }^{1}$, Ayu \\ Nurjanah $^{1}$, Nadia Nur Amalina ${ }^{1}$, Sri Musta'ina ${ }^{2}$ \\ ${ }^{1}$ Fakultas Kesehatan Masyarakat, ${ }^{2}$ Fakultas Kedokteran Universitas Airlangga \\ e-mail: cintia.maulina-2018@fkm.unair.ac.id
}

\begin{abstract}
Toddler, grup of children age ranging from 1-3 years old (under 3 years old) and 3-5 years old (preschool), is a vulnerable group to Covid-19 infection. Covid-19 caused by SARS-Cov 2 Virus that became a global pandemic since March 2020. Because of that, toddler care should be adjusted to health protocol given by the government in order to prevent the transmission of Covid 19. Generally, the knowledge and attitude of mothers at RW 1 Gondrong Subdistrict towards toddler care during Covid 19 pandemic are limited. Team 249 in Group 8 KKN BBN 62nd Airlangga University consider the need to educate the mothers to increase knowledge and attitude of toddler health and growth during pandemic. This health education is given to toddler's mothers who attends routine posyandu. The topic of health education given by the member of Team 249 is about toddler care during Covid 19 pandemic. Pre-test and post-test questionnaires are distributed to measure the knowledge and attitude before and after the education. The result shows that majority of the mothers whose age less than 35 years $(60 \%)$, have higher school education (70\%) and are housewives or unemployed $(80 \%)$. The ratio of post-test and pre-test score showed that the knowledge and attitude of toddler's mothers about toddler care during Covid 19 pandemic has increased. It is strongly suggested to be a new habit for the mothers to intensively care for their toddlers, especially during the Covid 19 pandemic.
\end{abstract}

Keywords: Attitude, Covid-19, Education, Knowledge, and Toddlers caring.

\section{abstrak}

Balita merupakan salah satu kelompok umur yang rentan terinfeksi Covid-19, penyakit disebabkan oleh Virus SARS-Cov 2 yang menjadi pandemi global sejak Maret 2020. Batasan usia balita adalah 1-3 tahun (batita) dan 3-5 tahun (pra sekolah). Oleh karena itu, perawatan balita pada masa pandemi covid-19 harus disesuaikan dengan protokol kesehatan yang ditetapkan pemerintah untuk memutus rantai penularannya. Akan tetapi, pada umumnya pengetahuan dan sikap ibu dari balita yang tinggal di RW 1 Kelurahan Gondrong Kota Tangerang kurang memahami hal tersebut. Kelompok 249 Grup 8 Kuliah Kerja Nyata BBM Periode 62 Universitas Airlangga memandang perlunya edukasi sebagai upaya untuk meningkatkan pengetahuan dan sikap para ibu terhadap kesehatan dan kecukupan tumbuh kembang untuk balita pada masa pandemi. Edukasi yang diberikan berupa penyuluhan kesehatan kepada para ibu yang menghadiri kegiatan rutin posyandu. Materi penyuluhan kesehatan yang disampaikan oleh anggota Kelompok 249 adalah mengenai perawatan balita pada masa pandemi Covid-19. Setiap ibu diberikan kuesioner pretest dan posttest untuk mengukur perubahan pengetahuan dan sikap ibu terhadap kesehatan balitanya sebelum dan sesudah mendengarkan penyuluhan. Hasil kegiatan ini menunjukkan karakteristik ibu yang mengikuti kegiatan mayoritas berusia kurang dari 35 tahun $(60 \%)$ dengan tingkat pendidikan SMA (70\%) dan status pekerjaan sebagai ibu rumah tangga atau tidak bekerja (80\%). Perbandingan skor pretest dan posttest menunjukkan adanya peningkatan pengetahuan dan perhatian mengenai kesehatan dalam merawat anak balitanya di masa pandemi Covid 19. 
Pengetahuan dan mengenaisikap mengenai kesehatan balita diharapkan menjadi kebiasaan baru yang dilaksanakan oleh para ibu dengan konsisten dalam merawat dan membesarkan anak balitanya, khususnya di masa pandemi Covid 19.

Kata kunci: Covid-19, edukasi, pengetahuan, perawatan balita dan sikap

\section{PENDAHULUAN}

Sejak akhir tahun 2019, dunia digemparkan oleh munculnya penyakit baru yang mirip pneumonia. Penyakit yang dikenal sebagai Covid-19 disebabkan oleh Virus Corona yang dinamakan SARS- Cov 2 (WHO, 2019). Virus ini utamanya menyerang sistem pernapasan yang mengakibatkan seseorang yang dapat mengalami gangguan pernapasan ringan, infeksi paru-paru berat, hingga menyebabkan kematian. Adapun seseorang yang terinfeksi Covid-19 menunjukkan berbagai gejala menyerupai flu antara lain demam, batuk kering, dan kelelahan (WHO, 2019). Penyakit Covid 19 pertama kali muncul pada Desember 2019 di Wuhan, Hubei, China. Virus ini mendadak menggemparkan dunia karna proses menginfeksi pada tubuh manusia yang menyebabkan kematian berlangsung sangat cepat. Sebanyak 216 negara telah dilanda pandemi, dan secara kumulatif kasus positif Covid 19 mencapai dengan 14.348.858 dan 603.691 kematian pada tanggal 20 Juli 2020 (World Health Organization, 2020).

Indonesia mengkonfirmasi kasus positif Covid-19 pertama kali pada Senin, 2 Maret 2020. Hal tersebut diumumkan oleh Presiden Joko Widodo bahwa terdapat dua Warga Negara Indonesia (WNI) yang positif terjangkit Virus Corona (Tim detikcomdetiknews, 2020). Penyakit Covid 19 telah ditetapkan sebagai pandemi di Indonesia sejak 11 Maret 2020, sehingga pemerintah mengeluarkan berbagai macam kebijakan untuk memutus rantai penularan Covid-19. Mulai dari pengeluaran kebijakan pemerintah di bidang pendidikan, bidang kesehatan, bidang sosial, kebijakan perdagangan ekspor-impor, UMKM (Usaha Mikro, Kecil, dan Menengah), penerapan PSBB (Pembatasan Sosial Berskala Besar), dan sebagainya (Kementerian Luar Negeri Republik Indonesia, 2020).

Dampak dari Covid-19 telah melumpukan aktivitas harian masyarakat. Perlu upaya yang konsisten dan terintegrrasi guna memutus mata rantai penyebaran Covid-19, terlebih lagi untuk melindung kelompok yang berisiko terjangkit seperti lansia, penderita penyakit kronis, perokok dan penghisap vape, kaum pria dan orang bergolongan darah A. Selain itu, batita dan anak pra sekolah juga merupakan kelompok yang berisiko terinfeksi Covid 19. Adapun usia batita yaitu 1-3 tahun, sedangkan usia anak pra sekolah adalah 3-5 tahun (D.L and J.F, 2014).

Direktur Pencegahan dan Pengendalian Masalah Kesehatan Jiwa dan Napza mengatakan bahwa pada tanggal 19 Juli 2020 sudah ada 7.008 anak Indonesia terinfeksi Covid-19, 8,6\% dirawat, 8,3\% sembuh, dan 1,6\% diantaranya meninggal (Nursanti, 2020). Klasifikasi berdasarkan usia pada anak yang menderita covid-19 adalah 5,8\% berusia 6-17 tahun dan 2,3\% balita (0-5) tahun (Nursanti, 2020). Angka kesembuhan untuk balita yaitu 2,3\% dan angka kematiannya 0,9\%. Oleh karena itu, Kementerian Kesehatan Republik Indonesia telah menerbitkan Panduan Pelayanan Kesehatan Balita pada Masa Pandemi Covid-19 dalam rangka pencegahan penularan Covid-19 pada balita dan anak pra sekolah. Puskesmas harus menjadi ujung tombak dalam mengidentifikasi keluarga yang memiliki anggota balita dan usia pra sekolah 
serta memberikan sosialisasi mengenai pencegahan penularan Covid-19, dan tetap memberikan edukasi mengenai cara menjaga kesehatan anak (Kementrian Kesehatan RI, 2020).

Kelurahan Gondrong adalah salah satu kelurahan yang ada di wilayah Kecamatan Cipondoh Kota Tangerang, Provinsi Banten. Jumlah penduduk usia 0-4 tahun di Kelurahan Gondrong sebesar 2.895 (Dinas Komunikasi dan Informatika, 2019). Banyaknya Balita di Kelurahan Gondrong dan adanya ketetapan pemerintah untuk mensosialisasikan upaya memutus rantai penularan Covid-19 khususnya pada balita, menjadi inspirasi Kelompok 249 Grup 8 KKN BBM Periode 62 Universitas Airlangga bekerja sama dengan Kader Kesehatan di RW 1 Kelurahan Gondrong. Kelompok 249 menyusun program Edukasi Perawatan Balita pada Masa Pandemi Covid-19 sebagai upaya memutuskan rantai penularan Covid 19 pada balita. Tujuan kegiatan ini adalah meningkatkan pengetahuan dan sikap ibu dari balita di RW 1 Kelurahan Gondrong, yang terdiri atas 5 RT, mengenai perawatan balita pada masa pandemi Covid-19 sebagai upaya pencegahan penularan covid-19 pada balita dan tetap memperhatikan kebutuhan tumbuh kembang dan kesehatan balita.

\section{METODE PENGABDIAN MASYARAKAT}

Metode pelaksanaan program pengabdian masyarakat ini adalah penyuluhan kesehatan. Materi penyuluhan yang diberikan adalah edukasi perawatan balita pada masa pandemic Covid 19. Sasaran kegiatan ini adalah para ibu yang memiliki balita toddler (1-4 tahun). Kegiatan penyuluhan dilakukan setelah posyandu. Materi edukasi disampaikan oleh Laras selaku mahasiswa dengan waktu penyuluhan 20 menit menggunakan media promosi berupa poster. Selanjutnya adalah diskusi tanya jawab selam 20 menit, dan diakhiri dengan pengisian lembar posttest oleh seluruh peserta, sebagai evaluasi. Penyuluhan kesehatan diakhiri dengan pemberian hadiah kuis berupa 3 set cuci tangan yang terdiri dari sabun cair dan wadah sabun.

Materi kuisoner mencakup pemberian ASI dan MP-ASI, gizi seimbang balita, penyemprotan desinfektan pada mainan balita, personal hygiene ibu dalam merawat balita, khususnya bagi Ibu balita dengan status PDP (Pasien Dalam Pengawasan). Hasil dari penyuluhan tersebut, dilakukan evaluasi dengan membandingkan skor kuesioner pretest dan posttest. Kuisoner terdiri dari penilaian pengetahuan dan sikap. Pemberian skor didasarkan pada rentang skor yang telah dibuat. Adapun rentang skor untuk kategori pengetahuan dibagi menjadi: pengetahuan baik dengan skor 60 100 dan pengetahuan kurang dengan skor $<60$. Sedangkan kategori sikap dibagi menjadi: sikap cukup baik dengan skor 12 - 24 dan sikap kurang dengan skor $<12$.

Dalam pelaksanaannya, dilakukan koordinasi dengan pihak kelurahan Gondrong dan jajaran pimpinan masyarakat RW 1, seperti Ketua dan Pengurus RW, para Ketua dan Pengurus RT, para Kader Kesehatan untuk mendukung tujuan dari pelaksanaan kegiatan. Jumlah ibu yang mengikuti dalam pelaksaan ini adalah 10 orang dan dibagi berkelompok masing masing 5 peserta. Jumlah peserta dibatasi mengingat kondisi ruangan yang tidak luas, serta untuk memenuhi peraturan pemerintah, yaitu membatasi jumlah personil untuk mencegah berkumpulnya masyarakat dalam jumlah yang besar (berkerumun) dan anjuran physical distancing tetap berlangsung. 


\section{HASIL DAN PEMBAHASAN}

Pelaksanaan kegiatan edukasi perawatan balita pada masa pandemi Covid-19 di Kelurahan Gondrong, Tangerang didukung oleh masyarakat. Hal tersebut dilihat dari jumlah kehadiran ibu dan keaktifan dalam proses kegiatan edukasi perawatan balita pada masa pandemi Covid-19 di Kelurahan Gondrong. Tangerang berlangsung. Kegiatan di hadiri oleh $10 \mathrm{ibu}$ yang memiliki balita. Adapun karakteristik usia, pendidikan, dan pekerjaan ibu yang mengikuti kegiatan edukasi perawatan balita pada masa pandemi Covid-19 di Kelurahan Gondrong, Tangerang dapat dilihat pada Tabel.1.

Tabel 1 Karakateristik Ibu Dalam Kegiatan Edukasi Perawatan Balita Pada Masa Pandemi Covid-19 Di Kelurahan Gondrong, Tangerang $(\mathbf{N}=\mathbf{1 0})$

\begin{tabular}{llll}
\hline No. & \multicolumn{1}{c}{ Variabel } & N & Persentase (\%) \\
\hline 1. & Usia: & 6 & \\
\hline & 25 - 35 tahun & 4 & 60 \\
& $>$ 35 tahun & & \\
\hline 2. & Tingkat Pendidikan & 2 & 20 \\
& SD & 1 & 10 \\
& SMP & 7 & 70 \\
SMA & & \\
\hline 4. & Pekerjaan orang tua & 2 & 20 \\
& Pedagang & 8 & 80
\end{tabular}

Pada Tabel 1, usia ibu yang mengikuti kegiatan kegiatan edukasi perawatan balita pada masa pandemi Covid-19 di RW 1 Kelurahan Gondrong, Tangerang lebih banyak berusia kurang dari 35 tahun (60\%) dengan tingkat pendidikan SMA (70\%) dan status pekerjaan sebagai ibu rumah tangga atau tidak bekerja (80\%). Kegiatan edukasi perawatan balita pada masa pandemi Covid-19 di Kelurahan Gondrong diawali dengan pengukuran pengetahuan para ibu dengan pretest dan diakhiri dengan posttest. Hasil pretest dan posttest didistribusikan berdasarkan jumlah jawaban benar para ibu yang mengikuti kegiatan.

Adapun hasil pretest dan posttest dapat di lihat pada tabel 2 berikut:

\begin{tabular}{|c|c|c|c|c|c|c|}
\hline \multirow{2}{*}{ No } & \multirow{2}{*}{ Jenis Tes } & \multicolumn{3}{|c|}{ Kurang } & \multicolumn{2}{|c|}{ Baik } \\
\hline & & $\mathbf{F}$ & & $\%$ & $\mathbf{F}$ & $\%$ \\
\hline 1 & Pretest & 5 & & 50 & 5 & 50 \\
\hline 2 & Posttest & 2 & & 20 & 8 & 80 \\
\hline
\end{tabular}

Hasil pretest pengetahuan ibu diketahui bahwa 5 dari 10 peserta memiliki pengetahuan yang kurang terkait upaya pencegahan penyakit Covid-19 pada balita. Rata-rata skor peserta yaitu 52, artinya sebagian besar peserta sudah memiliki pengetahuan yang kurang terkait dengan materi pencegahan Covid-19 pada balita. Setelah dilakukan kegiatan penyuluhan, peserta kembali mengisi lembar posttest, dan 
diperoleh hasil bahwa semua peserta mengalami peningkatan pengetahuan dengan rata-rata skor sebesar 89, sehingga kegiatan penyuluhan yang dilakukan oleh kelompok berhasil meningkatkan presentase pengetahuan peserta terkait upaya pencegahan penularan Covid-19 pada balita sebesar 58,4\% dari ibu yang memiliki pengetahuan kurang.

Tabel 3 Distribusi Frekuensi Sikap Ibu Dalam Kegiatan Edukasi Perawatan Balita Pada Masa Pandemi Covid-19 Di Kelurahan Gondrong, Tangerang $(\mathbf{N}=10)$

\begin{tabular}{ccccccc}
\hline No & Jenis Tes & Kurang & Baik & \\
& & F & & \% & F & \% \\
\hline 1 & Pretest & 6 & & 60 & 4 & 40 \\
2 & Posttest & 1 & & 10 & 9 & 90 \\
\hline
\end{tabular}

Hasil pretest sikap ibu menunjukkan bahwa 6 dari 10 memiliki skor < 12 yang dikategorikan dalam sikap kurang terhadap upaya pencegahan penularan Covid-19 pada balita sebelum kegiatan penyuluhan dilakukan. Namun, setelah kegiatan penyuluhan dan sesi diskusi dilakukan, terjadi peningkatan sikap pada 9 dari $10 \mathrm{ibu}$, dimana skor satu peserta lainnya stagnant dengan kategori yang sudah baik sejak sebelum kegiatan penyuluhan berlangsung. Tujuan pelaksaan pemberian edukasi perawatan balita pada masa pandemi Covid-19 di Kelurahan Gondrong, Tangerang adalah untuk menigkatan pengetahuan dan sikap para ibu dalam melakukan perawatan balita di era pandemi sehingga perawatan yang dilakukan para ibu dapat mecegah penularan Covid-19 pada balita dan tetap memenuhi kebutuhan tumbuh kembang balita dan kesehatan.

Dalam kegiatan ini para ibu belajar yang awalnya tidak tahu menjadi tahu. Hal ini serupa dengan penelitian yang dilakukan Amalia dkk (2018) bahwa kegiatan pemberiaan edukasi adalah proses interaksi antara manusia dan lingkungan yang dapat menghasilkan perubahan dalam pengetahuan, keterampilan serta sikap. Adapun beberapa faktor yang dapat mempengaruhi edukasi yaitu adanya komunikasi, sosial maupun training. Komunikasi yang terjalin dengan baik akan memberikan pengetahuan, sikap, kepercayaan dan lain sebagainya. Kondisi sosial yang baik akan memberikan ketersediaan fasilitas, sedangkan training yang baik akan memberikan pengaruh terhadap sikap dan perilaku.

Pemberian edukasi pada para ibu RW 01 kelurahan Gondrong, Kota Tangerang dalam perawatan balita di era pandemi mendukung perubahan perilaku kesehatan masyarakat menjadi lebih baik dengan didasari pemberian pengetahuan kesehatan selama pandemi Covid-19. Sehingga dari 5 ibu yang memiliki pengetahuan baik bertambah menjadi 8 ibu setelah diberikan edukasi. Pengetahuan yang terbentuk melalui pengalaman, pendidikan dan pelatihan. Proses pembentukan 
pengetahuan para ibu RW 1 yang memiliki balita dapat diperoleh dengan kegiatan edukasi perawatan balita pada masa pandemi Covid-19 di RW 1 Kelurahan Gondrong, Tangerang dan pemberian penyuluhan kesehatan secara berkala yang dilakukan saat posyandu akan sangat membantu para ibu untuk mencegah penularan Covid-19 dan meningkatkan perilaku kesehatan masyarakat dengan mengembangkan pengetahuan khususnya dalam meningkatkan kesadaran di era new normal. Menurut Schrader dan Lawless (2004) bahwa meningkatkan kesadaran dan pemahaman (seperti pengetahuan) merupakan intervensi kunci untuk mempengaruhi dan meningkatkan sikap dan perubahan perilaku (Sulistyorini, Rahfiludin and Suroto, 2019)

Hasil perubahan sikap pada ibu yang memiliki balita di RW 1 Kelurahan Gondrong, Kota Tangerang dapat ditemukan pada 5 ibu yang memiliki sikap baik sebelum dilakukan edukasi perawatan balita di era Covid-19 meningkat menjadi 9 ibu. Pemberian edukasi adalah upaya meningkatkan pengetahuan kesehatan yang menjadi dasar terhadap konsistensi perilaku seseorang. Selain itu perubahan sikap juga mempengaruhi perilaku seseorang. Hal ini serupa dengan penelitian Sulistyorini dkk (2019) yang menunjukkan bahwa sikap seseorang secara langsung signifikan mempengaruhi perilaku. Dimana sikap dianggap sebagai kesediaan individu untuk bertindak dan pelaksanaan motif tertentu. Dalam teori, sikap terbentuk melalui tiga tahap yaitu perhatian, pengertian, dan penerimaan Sehungga dengan adanya tujuan tertentu dalam edukasi perawatan balita di era Covid-19 diharapkan menimbulkan perhatian dan pengertian dalam diri para ibu yang kemudian terjadi penerimaan informasi yang dapat merubah sikap para ibu untuk bertindak mencegah penularan Covid-19 pada balita..

\section{PENUTUP \\ Simpulan}

Kegiatan pengabdian masyarakat oleh Kelompok 249 Grup 8 KKN BBN Periode 62 Universitas Airlangga berupa edukasi perawatan balita di masa pandemi Covid-19 telah dapat meningkatkan pengetahuan dan sikap para ibu yang memiliki balita yang menghadiri kegiatan edukasi dini di RW 1 Kelurahan Gondrong dalam upaya memutus rantai penularan Covid-19 kepada balita mereka. Edukasi yang diberikan juga telah meningkatkan kepedulian mereka dalam memperhatikan tumbuh kembang dan kesehatan balita mereka.

\section{Saran}

Dalam pelaksanaan pengabdian kepada masyarakat pada akhirnya timbul pemikiran baru yaitu

(a) perlu dilakukan pelatihan yang berkesinambungan bagi kader agar kemampuan untuk mandiri makin tinggi sebagai ujung edukasi kesehatan bagi masyarakat disekitarnya,

(b) perlu dilakukan penyuluhan kesehatan yang berkala seperti sharing dan diskusi untuk meningkatkan pengetahuan para ibu dari balita. 


\section{Ucapan Terima Kasih}

Kelompok 249 Grup 8 KKN BBM Periode 62 Universitas Airlangga menyampaikan penghargaan dan ucapan terima kasih atas bantuan dan kerjasama dari para kader kesehatan, para pengurus RT, dan para pengurus RW 1 Kelurahan Gondrong. Selain itu, Kelompok 249 Grup 8 KKN BBM Periode 62 Universitas Airlangga juga menyampaikan penghargaan dan ucapan terima kasih kepada DP2D (Dosen Pembina Pembangunan Desa) Ibu Sri Musta'ina, Dra., M.Kes., Koordinator Grup 8 Ibu Tania Ardiani Saleh Dra., M.S., Ketua Pelaksana KKN Nadia Nur Amalina, para pimpinan Fakultas dan Rektor Universitas Airlangga atas terselenggaranya KKN ini.

\section{DAFTAR PUSTAKA}

Amalia, F., Nugraheni, S. A. and Kartini, A. (2018) 'Pengaruh Edukasi Gizi Terhadap Pengetahuan dan Praktik Calon Ibu Dalam Pencegahan Kurang Energi Kronik Ibu Hamil (Studi pada Pengantin Baru Wanita di Wilayah Kerja Puskesmas Duren, Bandungan, Semarang)', Jurnal Kesehatan Masyarakat (e-Journal), 6(5), pp. 370-377.

D.L, P. and J.F, G. (2014) Pediatric Nursing : An Introductory Text. Canada: Elsevier.

Dinas Komunikasi dan Informatika (2019) Kecamatan Cipondoh Dalam Angka. Kota Tangerang. https://www.who.int/health-topics/coronavirus\#tab=tab_3 diakses pada tanggal 19 Juli 2020 pada pukul $12.00 \mathrm{WIB}$

https://www.who.int/emergencies/diseases/novel-coronavirus-2019 diakses pada tanggal 19 Juli 2020 pada pukul 09.00 WIB

Kementerian Luar Negeri Republik Indonesia (2020) Kebijakan Pemerintah Republik Indonesia Terkait Wabah Covid-19, kemenlu.go.id.

Kementrian Kesehatan RI (2020) 'Panduan Kesehatan Balita Pada Masa Pandemi Covid-19', pp. 1-60.

Nursanti, A. (2020) 7.008 Anak Indonesia Positif Covid-19 Kemenkes: 1,6 persennya Meninggal, Aktivitas Tetaplah di Rumah, PikiranRakyatcom.

Sulistyorini, A., Rahfiludin, M. Z. and Suroto, S. (2019) 'Determinan Perilaku Keselamatan Kerja: Peran Faktor Personal Penjamah Makanan di Warung Lesehan Malioboro', Jurnal Sains Terapan, 5(2). doi: 10.32487/jst.v5i2.677.

Tim detikcom-detiknews (2020) Kapan Sebenarnya Corona Pertama Kali Masuk RI?, news.detik.com.

World Health Organization (2020) Coronavirus Disease 2019-Situation Report 182, WHO. doi: 10.1213/xaa.0000000000001218. 